\title{
Analysis of Regional Supporting Force for the Development of Industrial Area in Order to Improve Regional Income in East Java, Indonesia
}

\author{
Sugeng Hadi Utomo ${ }^{1}$ \\ ${ }^{1}$ Faculty of Economics, Universitas Negeri Malang, Malang, East Java, Indonesia \\ Correspondence: Sugeng Hadi Utomo, Faculty of Economics, Universitas Negeri Malang, Malang, East Java, \\ Indonesia.
}

Received: December 1, 2015

Accepted: December 18, 2015

Online Published: January 19, 2016

doi:10.5430/ijfr.v7n1p219

URL: http://dx.doi.org/10.5430/ijfr.v7n1p219

\begin{abstract}
Industrial development is one of the pillars of national economic development, which are directed to apply the principles of sustainable development of industry based on the development aspects of economic, social, and environmental. Currently the construction industry is faced with global competition is very influential on the development of national industry. This research is descriptive qualitative and quantitative. Descriptive method of research tried to describe the relationship between phenomena or phenomenon under study systematic, factual, and accurate. While the sample is in local government 5 Regency/City in some regional work units (SKPD) relevant and Industrial Zone and a related deal or business entities that handle industrial estate in the area of research that is in Malang, Jember, Kediri, Bangkalan, and Tuban Regency. The results of the study are as follows: (1) Profile of Industrial Zone in East Java proper and suitable to increase revenue (PAD) are companies with a specific type of labor-intensive industries (2) What type fits and industry can be developed in the Industrial Area in East Java that has potential and strong competitiveness through industrial products are featured best products became the mainstay of exports of East Java, (3) Mapping the Industrial Zone in East Java.
\end{abstract}

Keywords: development of industrial area, regional income

\section{Introduction}

The era of globalization and economic liberalization has brought rapid change and far reaching impact on the economy, both nationally and internationally. The most perceived impact is an increasingly tight competition in various economic activities, especially in the industrial sector. To build a strong national economy in an environment of intense competition, the manufacturing sector as a productive sector producing high value added should be able to function as a motor of economic growth as well as a forming competitive advantage. Therefore we need more reformative and conducive policy settings to the achievement of these objectives, with a perfecting system of laws and regulations that already exist.

Despite that industrial sector is the motor of growth in the national economy, growth and advancement of the national industry must remain capable of inflicting maximum benefit for the prosperity for all citizens, permanent preservation of cultural values of noble nation characterized by economic democracy. Industrial development is one of the pillars of the development of the national economy, which is directed by applying the principles of sustainable development of industry based on the development aspects of economic, social, and environmental. Currently the construction industry is being faced with global competition is very influential on the development of national industry.

Increased competitiveness of industry is one option that should be done so that the national industry capable of competing products in the country and abroad. Measures in order to increase competitiveness and investment attractiveness of the creation of a conducive business climate, efficiency, legal certainty, and the provision of fiscal facilities and other easiness in business activities Industry, among others with the availability of adequate locations that form Industrial Zone industry. 
Table 1. Distribution industrial according to province in Indonesia

\begin{tabular}{ccccc}
\hline No. & Region & Amount & Total Area (Ha) & Percent (\%) \\
\hline 1 & Jakarta & 3 & $1,089.60$ & 3.63 \\
\hline 2 & Banten & 16 & $6,195.30$ & 20.62 \\
\hline 3 & West Java & 23 & $11,881.00$ & 39.55 \\
\hline 4 & Central Java & 6 & $1,445.00$ & 4.81 \\
\hline 5 & East Java & 7 & $2,185.00$ & 7.27 \\
\hline 6 & Riau & 11 & $2,666.40$ & 8.88 \\
\hline 7 & North Sumatera & 3 & $1,326.81$ & 4.42 \\
\hline 8 & West Sumatera & 1 & 200.00 & 0.67 \\
\hline 9 & Lampung & 1 & 300.24 & 1.00 \\
\hline 10 & East Sulawesi & 1 & 703.00 & 2.34 \\
\hline 11 & Central Sulawesi & 1 & $1,500.00$ & 4.99 \\
\hline 12 & East Kalimantan & 1 & 546.00 & 1.82 \\
\hline & Total Amount & $\mathbf{7 4}$ & $\mathbf{3 0 , 0 3 8 . 3 5}$ & $\mathbf{1 0 0 . 0 0}$ \\
\hline
\end{tabular}

Source: Ministry of Industry2013

Table 2. Land area industrial zone in some Indonesian island

\begin{tabular}{ccccc}
\hline No. & Region & Amount & Total Area (Ha) & Percent (\%) \\
\hline 1 & Java & 55 & $22,795.90$ & 75.89 \\
\hline 2 & Sumatra & 16 & $4,493.45$ & 14.96 \\
\hline 3 & Sulawesi & 2 & $2,203.00$ & 7.33 \\
\hline 4 & Kalimantan & 1 & 546.00 & 1.82 \\
\hline & Total amount & $\mathbf{7 4}$ & $\mathbf{3 0 , 0 3 8 . 3 5}$ & $\mathbf{1 0 0 . 0 0}$ \\
\hline
\end{tabular}

Source: Ministry of Industry2013

According to the Table 1 and Table 2 above, seem that the potential Industrial Area in East Java is still very large when it is developed. If seen from the growth of the industry and the number of Industrial unbalanced and very needed to develop. Therefore, the number of Industrial Area in East Java province needs to be developed or plus the area is, because there are many potential areas. Expected areas of Regency/City now have a need to be expanded or enlarged the area is. Areas currently have a need to create a new industrial estate. Furthermore, in the year 2013 forward, the Department of Industry and Trade of East Java (Industry and Trade) in East Java set up eight new Industrial Area. The plan eight regions in East Java province that will be projected as an Industrial Estate which will attract many investors to build a business. The eight areas are areas in Ring 2 East Java Province. Namely in Tuban, Lamongan, Banyuwangi, Lumajang, Pasuruan, Malang, Mojokerto, and Jombang.

East Java Province is the second largest contributor to the Indonesian economy with a growth rate similar to the national level and other major Provinces in Java. However, the province is expected to become one of the major economic centers in the country, this province experienced only a slight change in the economic structure in the last 10 years. Since 1995, the contribution of the industrial sector and agriculture in the economy almost unchanged. In addition, the growth of these two sectors is also low, whereas the industrial sector had been a major driver of the economy of East Java in the past. Employment in sectors with high productivity is also slow in recent years is that most of the workforce is still in the agricultural sector which is the sector with the lowest productivity compared to other economic sectors in the province. Private investment is expected to drive and move the economy towards sectors with higher growth turned out to be relatively small proportion compared with Jakarta, East Java and West Java. Overall conditions affecting the number of poor people in this province, which remains the highest in Indonesia, although over the last few years the poverty level decreased.

While the industrial center area is an area dominated by industrial households and small industries to be developed in the form of at distribution centers throughout East Java. Meanwhile, based on the direction of management, industrial 
allotment area should also pay attention to ecological aspects. That is not to be carried out on productive lands. In addition there must be also the green line as a buffer between the function of the area, facilities and infrastructure industries, as well as to be equipped with the introduction (frontage road) to smooth accessibility.

Development Industrial Zone is one of the means to develop environmentally friendly industries and provide convenience and attractiveness for investment. The construction of an industrial estate requires certain requirements that must meet the rules of technical feasibility, economic and financial; in addition to the support of government regulations and policies conducive, which is set in an Industrial Area Technical Guidelines. With the Technical Guidelines of Industrial Estate is expected to Local Government and related institutions can provide maximum service for the perpetrators of the investment in the development of industrial estate in the area. While the goal is for the Industrial Area developed in accordance with the layout, to minimize the negative impacts and maximize positive impacts on environment, efficient and effective, so that in turn is able to attract investment opportunities for industrial development in the area. Based on the background and explanations above, it is necessary to analyze the extent to which the role of supporting regional force for the development of Industrial area in order to improve Regional Income in East Java, Indonesia.

\section{Methods}

This research is descriptive qualitative and quantitative. Descriptive method of research tried to describe the relationship between phenomena or phenomenon under study systematic, factual, and accurate. The approach in this study is a qualitative and quantitative approach to describe the respondents to object based on questionnaires given. Assumptions are made due to the location of Industrial Zone located in areas with the potential to developed and under-developed Industrial Zone. Under these conditions, the basis of these studies, which is expected with the expansion of industrial estate can synergize with existing land use around since the Industrial Area is directly related to economic factors.

The population in this study is the regional government of East Java Province. While the sample is in local government 5 Regency/City in some regional work units (SKPD) relevant and Industrial Zone and a related deal or business entities that handle industrial estate in the area of research that is in Malang, Jember, Kediri, Bangkalan, and Tuban Regency. Purposive sample was taken from each of the parts, which are considered relevant and important can represent for this study.

Techniques of data collection were done by using observation, questionnaire, interview, documentation techniques, Study Results Evaluation. Qualitative data analysis model used in this research is the analysis of data developed by Miles and Huberman performed with interactive models through the process of data reduction, display data, and verification.

\section{Results and Discussion}

According to the Chairman of the Indonesian Industrial Estates Association (2014), says that "the growth of Industrial Area in Indonesia is always slower than the growth in demand for land in the last three years ", Indonesia's economic growth is positive trigger high demand. However, growth is not matched by the development of a new industrial estate.

Indonesian Industrial Estates Association (HKI) highlights some of the things that cause difficulty in the development of new industries. First, the process of land acquisition, second; Land clearing process. Additionally, for the Industrial Zone in the outer islands, the infrastructure is still minimal, making it difficult to develop the industry in a short time. "Government regulations regarding the broad restrictions Industrial Zone is also a barrier."Growth in Industrial Area which is lower than the growth in demand, does not directly make investors fail to invest in Indonesia. The impact over the delay realization of any investment.

Industrialization in East Java alone managed to shift economic activity, of which relies on agriculture into the industrial sector. But because most of the people of East Java livelihood as farmers and economic resources are abundant in the agricultural sector, the Industrial Development Policy in East Java prioritize three pillars of industrial development, one of which is the agro industry. With economic endowment in the agricultural sector, the industry should be based on the sector, so it will not cause the problem of unemployment and income inequality.

Agroindustry is a branch of industry which has close links with agriculture and direct. When agriculture is defined as the process that produces at the level of primary agricultural products, the industry can do with respect to backward linkage and forward linkage. East Java (Pasuruan, Sidoarjo, Gresik, Ngoro and vicinity) loser has got great potential to become the basis for the growth of the industry serving national and multinational companies. 
The companies with the specific type of labor intensive industries such as the food industry, beverages, and consumer goods, will open a factory in the industrial area of East Java. They opened a new factory as part of business expansion and there are also companies that have recently opened a factory in the industrial area according to the Ministry of Finance No. 120/2013, which requires companies operate factories in the industrial area. Although in general the growth of the industrial area slowed in 2014, and land absorbed by the market is predicted to only 350 hectare, but the East Java will grow rapidly. This was driven by abundant labor factor and also low wages.

Two of these factors triggers glanced industrial areas in East Java by new companies or are already operating in Cikarang, Bekasi (West Java), but want to expand or even relocate their business. Not surprisingly, sales during the quarter of 2014 alone, according to data IPR, sold a 35 hectare land in the industrial area of East Java, West Java relocation.

\subsection{Suitable Types of Industry That Can Be Developed in Industrial Area in East Java}

East Java Province is one of the areas that have the potential and strong competitiveness through industrial products featured his best. This is because it is supported by innovative human resources as capital for community economic development in East Java. Development and growth of SMEs today, cannot be separated from their commitments and policies and programs run by the government of East Java province that continues until today. All of them carried out with a determination and spirit that the growth of SMEs in East Java province can continue to grow in a healthy and strong so that it can become integral to the activities of the industry, and is able to make a significant contribution in strengthening the domestic economy.

Meanwhile, some of the East Java provincial government programs that have been implemented in an effort to develop the potential of SMEs in the Regency/City, among others, the restructuring of machinery and equipment, development of entrepreneurship, coaching and approaches One Village One Product (OVOP) food products, clothing, and crafts, as well as the development of SMEs through the cluster approach, in which there are assisted design experts who are able to produce products that the public interest even for export purposes.

In regard to the implementation of the ASEAN Economic Community (AEC) 2015, it is expected the perpetrators of SMEs more eager to work harder and be more creative in enhancing the competitiveness of products, among others, to register Intellectual Property Rights (IPR) works to prevent counterfeiting products which conducted by other countries, as well as improved quality and design development to provide added value and strengthen the competitiveness of the products produced. Below the main commodity products exported from East Java Province in the table below.

\section{Main Commodity Products (Export) of East Java Province}

\begin{tabular}{|c|c|c|}
\hline No & Main Commodity & Export Destination \\
\hline 1 & Textile and Textiles Product & $\begin{array}{l}\text { United States, Japan, Germany, Turkey, Korea, Republic Of, United } \\
\text { Kingdom, United Arab Emirates, China, Brazil, Malaysia, Belgium, } \\
\text { Italy, Netherlands, Spain, Canada, Saudi Arabia, Thailand, France, Viet } \\
\text { Nam, Taiwan }\end{array}$ \\
\hline 2 & Electronic & $\begin{array}{c}\text { Singapore, United States, Japan, Hong Kong, China, Germany, Malaysia, } \\
\text { Netherlands, Korea, Republic Of, Philippines, France, Thailand, India, } \\
\text { Australia, United Arab Emirates, United Kingdom, Taiwan, Viet Nam, } \\
\text { Belgium, Italy }\end{array}$ \\
\hline 3 & rubber & $\begin{array}{l}\text { United States, Japan, China, Korea, Republic Of, Singapore, Brazil, } \\
\text { Germany, Canada, Netherlands, Turkey, France, India, Spain, Italy, } \\
\text { United Kingdom, Belgium, Taiwan, South Africa, Australia, Argentina }\end{array}$ \\
\hline 4 & Palm Oil & $\begin{array}{l}\text { India, China, Malaysia, Bangladesh, Netherlands, Egypt, Singapore, } \\
\text { Italy, Spain, Ukraine, Iran,islamic Rep. Of, Russian Federation, Pakistan, } \\
\text { Germany, Tanzania, Un.rep. Of, Brazil, South Africa, Viet Nam, } \\
\text { Myanmar (formerly Burma), Kenya }\end{array}$ \\
\hline 5 & Forest Product & $\begin{array}{c}\text { Japan, China, United States, Korea, Republic Of, Australia, Malaysia, } \\
\text { Taiwan, Saudi Arabia, United Arab Emirates, India, Germany, } \\
\text { Netherlands, United Kingdom, Viet Nam, Singapore, Belgium, Italy, } \\
\text { France, Bangladesh, Thailand }\end{array}$ \\
\hline
\end{tabular}




\begin{tabular}{|c|c|c|}
\hline 6 & Shoe, sandals & $\begin{array}{c}\text { United States, Belgium, Germany, United Kingdom, Netherlands, Italy, } \\
\text { Japan, Mexico, France, Brazil, China, Denmark, Panama, Korea, } \\
\text { Republic Of, Singapore, Spain, Australia, Russian Federation, Chile, } \\
\text { South Africa }\end{array}$ \\
\hline 7 & Otomotive & $\begin{array}{l}\text { Thailand, Japan, Saudi Arabia, Philippines, Malaysia, Singapore, United } \\
\text { Arab Emirates, South Africa, Brazil, Vietnam, China, Mexico, Oman, } \\
\text { United States, Taiwan, United Kingdom, Myanmar (formerly Burma), } \\
\text { Germany, India, Kuwait }\end{array}$ \\
\hline 8 & Shrimp & $\begin{array}{c}\text { United States, Japan, China, United Kingdom, Belgium, Hong Kong, } \\
\text { Vietnam, Singapore, France, Canada, Australia, Malaysia, Taiwan, } \\
\text { Russian Federation, Netherlands, Italy, Germany, Korea, Republic Of } \\
\text { Denmark }\end{array}$ \\
\hline 9 & cocoa & $\begin{array}{c}\text { Malaysia, United States, Singapore, China, Spain, Germany, France, } \\
\text { Netherlands, United Kingdom, Australia, Philippines, India, Canada, } \\
\text { Thailand, Japan, Brazil, United Arab Emirates, Estonia, Russian } \\
\text { Federation, New Zealand }\end{array}$ \\
\hline 10 & Coffee & $\begin{array}{l}\text { United States, Japan, Germany, Italy, Malaysia, Belgium, United } \\
\text { Kingdom, Russian Federation, Egypt, Morocco, India, Taiwan, Canada, } \\
\text { Australia, Georgia, Singapore, Algeria, Ecuador, France, South Africa }\end{array}$ \\
\hline
\end{tabular}

Source: Export Import of East Java

Potential Product of East Java Province

\begin{tabular}{|c|c|c|}
\hline No & Main Products & Export Destination \\
\hline 1 & coal & Korea, Arab, Germany \\
\hline 2 & Leather and Leather Products & $\begin{array}{l}\text { Hongkong, India, Vietnam, China, Germany, Singapore, Korea, } \\
\text { Italia, Malaysia, Thailand, Spanyol, Taiwan, Japanesse, Kamboja, } \\
\text { Sri Lanka, South africa, France, Philippines, USA, Mexico }\end{array}$ \\
\hline 3 & Medical Equipment & $\begin{array}{c}\text { Singapore, Germany, Japanesse, USA, India, China, Belanda, } \\
\text { Malaysia, Afghanistan, Thailand, Taiwan, Kenya, Iran, Kanada, } \\
\text { Hong Kong, France, Australia, Timor Timur, Saudi Arabia, } \\
\text { Philippina }\end{array}$ \\
\hline 4 & Medicinal Plant & $\begin{array}{c}\text { India, Malaysia, USA, Taiwan, Japanesse, Singapore, France, } \\
\text { Belanda, Germany, Swiss, Korea, Vietam, Australia, Hong Kong, } \\
\text { Argentina, Thailand, England, Saudi Arabia, United Arab } \\
\text { Emirates, Jordania }\end{array}$ \\
\hline 5 & Processed food & $\begin{array}{l}\text { United States, Malaysia, Philippines, Singapore, Japan, China, } \\
\text { Cambodia, Thailand, Vietnam, Saudi Arabia, Netherlands, } \\
\text { Germany, Hong Kong, Australia, Belgium, United Kingdom, } \\
\text { India, Spain, Korea, Republic Of Taiwan }\end{array}$ \\
\hline 6 & Essential Oil & $\begin{array}{c}\text { United States, Singapore, France, India, Switzerland, Spain, } \\
\text { Germany, Netherlands, China, United Kingdom, Mexico, United } \\
\text { Arab Emirates, Turkey, Italy, Brazil, Japan, Pakistan, Hong Kong, } \\
\text { Taiwan, East Timor }\end{array}$ \\
\hline 7 & Fish and Fish Product & $\begin{array}{c}\text { Japan, United States, Thailand, Vietnam, China, Singapore, } \\
\text { Malaysia, Italy, Korea, Republic Of, Hong Kong, Taiwan, Spain, } \\
\text { Russian Federation, Australia, Belgium, Netherlands, France, } \\
\text { Germany, United Kingdom, Iran }\end{array}$ \\
\hline 8 & Craft & $\begin{array}{c}\text { United States, Japan, United Kingdom, Germany, Australia, } \\
\text { France, Netherlands, Korea, Republic Of, Spain, Singapore, Italy, } \\
\text { Canada, Taiwan, Belgium, South Africa, Malaysia, Sweden, } \\
\text { United Arab Emirates, China, Brazil }\end{array}$ \\
\hline
\end{tabular}

Source: Export Import of East Java 


\subsection{Step Strategic in Provincial Government of East Java}

In East Java Province existing Industrial Estate Information System (SIKI) is a database of information technology-based industrial areas as an online based system of media publications related to the promotion of industrial estates in East Java. Information Systems Industrial Zone (SIKI) made in the year 2013 and is managed by the Department of Industry and Trade ( Industry and Trade ) of East Java Province under the auspices of Sector IATT (Industrial Electronics Transport Equipment and Telematics), which has the objective:

3.2.1 As access to make it easier for potential investors in finding a strategic location for business development.

3.2.2 Provides information on industrial estates that have been developed or planned industrial zones will be developed in East Java in a systematic and easily accessible by the general public.

3.2.3 Providing information on the location of the distribution of well-developed industrial estates and industrial zones are planned to be developed in the East by mapping the industrial area in a map.

3.2.4 Help provide information to other industries where the industrial area, industrial area managers, land area, number of enterprises, the availability of land (occupancy), and the planned development of the industrial area.

3.2.5 Promote the industrial area of East Java to the general public, especially in East Java, the Indonesian people and even the international community.

\section{Conclusion}

Furthermore, based on the results of research and analysis supported as described in the previous chapter, as well as attention to the problem of research and formulation of the problem, it can be concluded the results of the study are as follows. 1) Profile of Industrial Zone in East Java proper and suitable to increase revenue (PAD) are companies with a specific type of labor-intensive industries such as agro-industry and food industry, beverages, and consumer goods, it is driven by the labor factor abundant and well minimum wage. 2) What type fits and industry can be developed in the Industrial Area in East Java that has potential and strong competitiveness through industrial products are featured best products became the mainstay of exports of East Java. 3) Mapping the Industrial Zone in East Java, which can be developed and a very good prospect is in Sidayu Gresik, Tuban Industrial Estate, Wonorejo Banyuwangi, Pasuruan Industrial Estate Rembang (PIER), Jombang Ngoro Industrial Park (NIP), Wonorejo Banyuwangi, Tuban Industrial Estate, and Brondong Lamongan.

Based on result and discussion there are strategic measures Provincial Government of East Java to the development of industrial estate: a) Establish industrial products are prioritized; b) Proposes acceleration of the implementation of safeguards and anti- dumping; c) Develop the National Competence Indonesia (SKKNI); d) Develop strategies of industrial development according to the National Industrial Policy (KIN); e) Establish Roadmap Leading Industry Development in East Java; f) On the Leading Industry Development Roadmap, providing a shared responsibility between the Core Competence Industrial District/City . Provinces, the central government through the Ministry of Industry, and other relevant stakeholders; g) Create a program of activities and industrial development in the area synergistic and sustained between the Central Government and Local Government; $h$ ) Local governments are required to proactively undertake industrial development in accordance with the Roadmap that has been set.

\section{Recommendation}

Based on the above conclusions and recommendations then given recommendations and suggestions for improvements in the future are as follows: 1) In order to accelerate the development of industrial estates in East Java so that prospective investors are interested in investing in East Java, the Provincial Government of East Java, should immediately encourage/motivate and help the problems in areas that are prioritized into industrial area. 2) In order to provide information on the well-developed industrial area and the industrial area which is planned to be developed systematically in East Java is known and accessible to potential investors in the country and abroad, should East Java Provincial Government through the website (internet) and fairs abroad. 3) In order to provide information about the distribution locations Industrial Zone which has been developing and industrial areas are planned to be developed in East Java, should the Provincial Government of East Java mapping the industrial area in a map through a website (internet) and exhibitions abroad. 4) In order to provide easiness of permitting, public administration and technical needs, land, electricity and water, labor, should East Java Provincial Government through the website (internet) and exhibitions abroad. 


\section{References}

Diagnosa Pertumbuhan Ekonomi JawaTimur: Mengidentifikasi Hambatan-Hambatan Utama Pertumbuhan yang Inklusif di Provinsi Terbesar Kedua di Indonesia, tahun 2011, Bank Dunia.

Direktorat Jenderal Pengembangan Perwilayahan Industri. Peningkatan daya saing industry daerah melalui pengembangan pusat-pusat pertumbuhan industri, tahun 2013, di Jakarta.

Jember Dalam Angka, 2010-2008

Pearie John dan Robinson. (2008). Manajemen Strategis, Edisi ke-10. Salemba Empat, Jakarta.

Peraturan Daerah Kabupaten Bangkalan Nomor 10 Tahun 2009, tentang Rencana Tata Ruang Wilayah Kabupaten Bangkalan Tahun 2009 - 2029

Peraturan Daerah Kabupaten Kediri Nomor 14 tahun 2011 Tentang Rencana tata ruang wilayah Kabupaten Kediri Tahun 2010-2030

Peraturan Daerah Kabupaten Malang Nomor 3 Tahun 2010 Tentang Rencana Tata Ruang Wilayah Kabupaten Malang

Peraturan Daerah Kabupaten Nomor 09 tahun 2012, Tentang Rencana tata ruang wilayah Kabupaten Tuban Tahun $2012-2032$

Peraturan Daerah Provinsi Jawa Timur Nomor 1 tahun 2009,Tentang Rencana pembangunan jangka panjang daerah Provinsi Jawa Timur tahun 2005- 2025.

Peraturan Daerah Provinsi Jawa Timur Nomor 5 tahun 2012, Tentang Rencana tata ruang wilayah Provinsi Tahun 2011-2031.

Peraturan Menteri Dalam Negeri Nomor 29 tahun 2008, Tentang Pengembangan kawasan strategis cepat tumbuh di daerah.

Peraturan Menteri Keuangan Nomor 120 tahun 2013 sebagai revisi Peraturan Menteri Keuangan Nomor 147 tahun 2011 tentang kawasan berikat

Peraturan Menteri Perindustrian Republik Indonesia Nomor 156/M-IND/per/ 12/2012, Tentang Peta panduan pengembangan kompetensi inti industry kota Mojokerto.

Peraturan Menteri Perindustrian Republik IndonesiaNomor: 35/M-IND/per/3/2010 Tentang Pedoman teknis Kawasan Industri.

Peraturan Pemerintah Nomor. 27 tahun 1999 Tentang :analisis mengenai dampak Lingkungan Hidup.

Peraturan Pemerintah Republik Indonesia Nomor 24 tahun 2009 Tentang Kawasan Industri.

Peraturan Pemerintah Republik Indonesia Nomor 26 tahun 2008, Tentang Rencana tata ruang wilayah nasional.

Peraturan Pemerintah Republik Indonesia Nomor 27 tahun 2012, Tentang Izin lingkungan.

Profil Potensi Investasi Provinsi Jawa Timur, tahun 2012, BKPM.

Rencana Pembangunan Jangka Menengah, Kabupaten Jember, 2006-2010.

Sugiyono. (2010). Metode Penelitian Kuantitatif Kualitatif dan RD, Alfabeta, Bandung.

Undang-Undang Nomor 3 tahun 2014, tentang Perindustrian.

Undang-undang RI Nomor 32 Tahun 2004, tentang Pemerintahan Daerah. 